\title{
Ekonomická teória a niektoré problémy jej chápania
}

\section{Economic theory and some problems of its understanding}

\section{Jozef Horeháj, Ivana Kuráková}

Abstract: Economic theory is a basis for the study of economic issues and the approach to it determines the formation of different views in society. The aim of the paper is to highlight the areas of economics that have caused problems in the educational process, but also their understanding by public is more or less distorted. The core of the paper is based on our own experience in teaching economics and working at Faculty of Economics, Matej Bel University in Banská Bystrica, as well as the analysis of the literature. Based on the synthesis of the acquired knowledge 3 areas of problems of economic theory were selected, on which the paper focuses: the market and the functioning of the market mechanism, the labour market and the problem of unemployment and the market $v$ s. state in terms of macroeconomic theory. For each of these problems, it is necessary to know the historical context of the current state, which also emphasizes the importance of knowing the history of economic theories. The authors of the article perceive the understanding of economic theory in the context of other social sciences as a key, which makes it possible to obtain a comprehensive picture of society.

Key words: Economic theory. Market vs. State. Social sciences.

JEL Classification: A10. A11.

\section{Úvod}

Ekonómiu ako teoretický odraz hospodárskej činnosti možno pokladat’ za spoločenskú vedu s istým „osobitým statusom“. Jednak sa týka l'udských aktivít zabezpečujúcich fyzickú (biologickú) existenciu človeka a zároveň $\mathrm{v}$ hospodárskych procesoch a vzt'ahoch sa formovali mnohé civilizačné prvky - inštitúcie, pravidlá, princípy - umožňujúce spoločenský vývoj, pokrok. Má preto širší spoločenský význam a vplyv.

Ekonomická teória je prirodzeným základom (východiskom) pre štúdium ekonomickej problematiky. Charakter a obsah ekonomických vzt’ahov vyžaduje užšie prepojenie ekonómie 
s kvantitatívnymi disciplínami - matematikou, štatistikou - ale aj s politikou, psychológiou a v ostatnom období s ekológiou. Hlbšie pochopenie jej významu a zmyslu v spoločenskom poznaní vyžaduje vnímanie ekonómie v kontexte s humanitnými a spoločenskými vedami. Ciel’om článku je vyzdvihnút' oblasti ekonómie, ktoré robili problémy vo vzdelávacom procese, ale aj vo verejnosti je ich chápanie viac či menej skreslené.

\section{Teoretické východiská}

Za posledných tridsat' rokov sa $\mathrm{v}$ našich transformačných podmienkach etablovala štandardná podoba ekonómie, odrážajúca „zmiešanú ekonomiku“ (mixed economy), v jej dvoch vetvách - monetaristickej (liberálnej) a keynesovskej (intervencionistickej). Štruktúra ekonómie zahŕňa mikroekonómiu a makroekonómiu, v rámci ktorých (alebo samostatne) sú prezentované vonkajšie ekonomické vzt’ahy a história vedy. Podl'a konkrétneho zamerania vzdelávacieho programu je prispôsobovaný aj konkrétny obsah celej problematiky.

Niektoré skúsenosti z výučby ekonomickej teórie v uvedenej štruktúre na Ekonomickej fakulte i d’alších fakultách Univerzity Mateja Bela (d’alej len „UMB“) v Banskej Bystrici sú prvotným východiskom, ktoré poskytlo cenné praktické poznatky zo vzdelávacieho procesu. Za tri desat'ročia možno na jeho základe identifikovat' postupné zmeny vo všeobecnom chápaní problematiky študentmi, a najmä tematické okruhy, pojmy, kategórie, vzt'ahy a procesy, ktoré im robili pri štúdiu problémy. Spravidla boli odrazom všeobecne nižšej úrovne ekonomického vedomia $\mathrm{v}$ spoločnosti a osobitostí transformačného a post transformačného vývoja.

Pri komparácii s poznatkami západných teoretikov - Samuelson, Heyne, Caplan, Pipes, Huerta de Soto a i. - sa preto naše poznatky sčasti líšili od tých, ktoré boli zovšeobecnením ich skúseností, ale značná čast' problémov pri teoretickom ekonomickom vzdelávaní má vel'mi podobné črty na „oboch“ stranách. Podobné konštatovanie sa týka aj chápania a vnímania ekonomických poznatkov vo verejnosti, pričom východiskové poznanie študentov spravidla odráža poznatky všeobecne rozšírené v spoločnosti. Predovšetkým je značne rozšírený názor, že ekonomiku, využívajúcu v rozsiahlej miere matematiku, štatistiku a modelovanie, je možné pomerne precízne riadit' a regulovat' $z$ úrovne centrálnych mocenských inštitúcií a ekonomická teória by mala optimálne podmienky fungovania ekonomiky pomocou kvantitatívnych metód a organizačno-riadiacich modelov pomerne presne vymedzovat'.

Ekonómii sa pripisujú možnosti exaktných vied, ktoré umožňujú aj pomerne presné predpovede jednoduchých fyzikálnych procesov do budúcnosti. Ekonómia je však 
spoločenská veda snažiaca sa za existencie obrovského množstva premenných charakterizovat' podstatu ekonomických procesov založených na formovaní spoločenskej koordinácie činností indivíduí sledujúcich vlastné záujmy, prospech (Sedláček, 2009). Indivíduá pritom volia, vyberajú racionálne, teda riadia sa prepočtom nákladov a prospechu, čo však neznamená, že l’udia všetko vedia a nikdy sa nemýlia či nerobia chyby.

Ekonómia skúma aj rámec a pravidlá, podl'a ktorých l'udia pri vol'be a rozhodovaní konajú. Všeobecným rámcom je trhový systém a rozhodujúcu čast' pravidiel formujú vlastnícke práva, pričom nemožno presne vymedzit' hranice „ekonomického sektora“; ekonómie, ktorá sa pritom prelína s inými spoločenskými oblast’ami.

Pochopenie podstaty a zmyslu ekonómie nie je vždy jednoduché ani pre študentov ekonomických disciplín. Zjednodušene možno vymedzit’ jeho podstatu Keynesovými slovami „Ekonomická teória neposkytuje súbor ustálených záverov ihned' využitel'ných v hospodárskej politike. Je to skôr metóda, než doktrína, nástroj myslenia, technika myslenia, ktorá pomáha svojmu majitel’ovi dospiet’ k správnym záverom“ (Heyne, 1991, s. 7). Už v úvode štúdia tak možno korigovat' niektoré predstavy o jeho ciel'och a možnostiach.

\section{Materiál a metódy skúmania}

Ciel’om článku je vyzdvihnút' oblasti ekonómie, ktoré robili problémy vo vzdelávacom procese, ale aj vo verejnosti je ich chápanie viac či menej skreslené. Vychádzame z vlastných skúseností učitel’ov pri výučbe ekonómie na katedre ekonómie Ekonomickej fakulty UMB, ale aj z poznatkov získaných v rámci medzikatedrovej i medzinárodnej spolupráce (Česká republika, Francúzsko, Pol'sko) vo forme konferencií, workshopov, seminárov, zborníkov, článkov, testov, dotazníkov, ktoré sme získali v priebehu troch desat'ročí.

Tieto poznatky sme priebežne dopĺn̆ali a konfrontovali s poznatkami z adekvátnej literatúry, najmä západných autorov, a reálnej transformačnej a post transformačnej praxe a hospodárskej politiky.

Všetky materiály sme analyzovali, vyhodnotili pomocou teoretických aj empirických metód, čiastočne komparovali a zovšeobecnili. Na základe syntézy získaných poznatkov sme pre potreby tohto článku, rešpektujúc jeho možný rozsah, vybrali tri oblasti problémov ekonomickej teórie - dve z mikroekonómie a jednu z makroekonómie - pričom na začiatku stručne vyzdvihujeme význam histórie pre hlbšie pochopenie teoretickej problematiky.

\section{Výsledky a diskusia}


Kontinuita hospodárskych procesov ukazuje, že ekonomická problematika má aj svoju historickú dimenziu, najmä v podobe hospodárskych dejín a dejín ekonomického myslenia. Význam dejín ekonomických teórií je predovšetkým v objasňovaní, ako sa v nepretržitosti ekonomického vývoja formovali ekonomické poznatky, názory, koncepcie, ekonómia ako veda až po súčasný mainstream. Historický pohl’ad umocňuje pochopenie času ako jednej zo základných ekonomických kategórií - história je časová hĺbka, tretí rozmer hospodárskeho diania, ktorý dáva zmysel aj teoretickému skúmaniu.

Takýto pohl'ad pomáha pochopit', prečo sú ekonomické názory diferencované, aj prečo ekonomické problémy nemusia mat' len jedno správne riešenie. Množstvo neznámych a premenných $\mathrm{v}$ ekonomike spolu s rôznymi metodologickými postupmi a hodnotovými systémami, charakterom a obsahom ekonómie môžu viest' $\mathrm{k}$ rôznym podobám ekonomického poznania. K ich lepšiemu chápaniu prispievajú aj historické poznatky o súvislostiach hospodárskeho a spoločenského vývoja, prelomových udalostiach a obdobiach, a pod.

Historický rozmer je dôležitý aj pre skúmanie vzt’ahu ekonómie s politikou a spoločenskými a humanitnými vedami rozširujúcimi komplexné poznanie fungovania a charakteru spoločnosti. Vzdelávacím problémom dejín ekonomických teórií je náročnost' obsahu i rozsah celej problematiky (predmetu), ktoré vyžadujú hl’adanie optimálnej podoby vysvetl'ovania a zaradenia $\mathrm{v}$ rámci konkrétnych študijných programov - zaradit' ako úvod, záver mikro- či makroekonómie, pri ich jednotlivých témach alebo ako samostatný predmet vo vyšších ročníkoch.

V dlhodobom sledovaní možno konštatovat', že pri problematike dejín ekonomických teórií má negatívny vplyv všeobecne nízka znalost' najmä histórie a filozofie. História ekonómie odrážala nielen logiku jej vzniku a formovania, ale aj reálne hospodárskospoločenské podmienky daných období. Spojitost' ekonómie $\mathrm{s}$ inými spoločenskými oblast'ami dokumentuje aj skutočnost', že zakladatel'om ekonómie v 18. storočí bol filozof, ktorého predstava fungovania hospodársko-spoločenského systému sa stala jadrom ekonomického poznania. Jeho rozvoj asi o storočie zásadne rozšírilo a prehíbilo formulovanie hraničného princípu. V 20. storočí mal zásadný vplyv na vývoj ekonomickej teórie rast štátnych intervencií a formovanie makroekonómie.

\subsection{Trh a trhový mechanizmus}

Obsah mikroekonómie v štandardnej podobe dnes prezentuje väčšina učebníc a jeho jadrom je problematika trhu, fungovania trhového mechanizmu, trhových vzt'ahov všeobecne. Je základom ekonomického skúmania a výkladu. Vznik trhu je spojený so vznikom výmeny, 
obchodu a del'by práce a stal sa základom ekonomických vzt'ahov v období l’udskej civilizácie. Aj tu je historická dimenzia osobitne dôležitá. Dokumentuje objektívnost' vzniku a evolučného vývoja trhu, jeho rozhodujúcich prvkov a predpokladov - súkromného vlastníctva a del'by práce.

Spoločenskú podstatu a význam trhu možno súhrnne a stručne vyjadrit' tak, že „trhový systém je spontánne evolučne vzniknutý a rozvíjaný hospodársky systém mierovej adaptácie l'udskej spoločnosti, ktorý bol najefektívnejšou odpoved'ou na obmedzenost' (vzácnost') zdrojov a ktorý optimálne reflektuje neustálu zmenu prírodných, technologických a spoločenských podmienok“.

Význam vynikne viac, ak zdôrazníme, že alternatívou trhu je boj o zdroje, konflikty, vojny, ktorých sú l’udské dejiny, žial', plné a ktorých pokračovanie do budúcnosti pri existujúcich vojenských prostriedkoch by bolo istou cestou do skazy civilizácie. Nielen ekologické problémy, ale aj deformácia či likvidácia trhových vzt’ahov ako jedného z pilierov civilizácie môže spôsobit' jej zánik.

Vo výučbe spravidla nebýva problém s pochopením fungovania trhového mechanizmu a príslušných kategórií, najmä ak sa vysvetl'ujú v historicko-evolučných súvislostiach. Isté problémy sú s chápaním podstaty a spoločenského významu, resp. praktickým fungovaním trhu. Nielen v ekonomickej sfére, ale aj v spoločnosti možno dlhodobo pozorovat' odpor k trhu, najmä od obdobia rozvoja modernej priemyselnej ekonomiky. Rast tejto tendencie zrejme odráža dopady rozvoja priemyslu na hospodársky a spoločenský život, zmeny hospodárskej a spoločenskej štruktúry, dopady rôznych ideológií, stotožňovania trhu s kapitalizmom a pod. V spoločnosti je trh dlhodobo terčom kritiky, spochybňovania či odmietania z rôznych dôvodov, strán, pozícií, ktoré sa rozširujú najmä posledné storočie až do súčasnosti a vrcholia začiatkom 21. storočia v koncepcii „trhového fundamentalizmu“, propagovaného na teoreticko-akademickej, mediálnej i „laickej“ úrovni.

Pochopitel'ne, väčšina ekonómov aj adeptov ekonómie zrejme chápe význam trhu v hospodárskom systéme a akceptuje jeho nedokonalosti v podobe ,zlyhaní trhu“ i štandardné možnosti ich riešenia, na rozdiel od vel'kej časti verejnosti, nielen v postkomunistických krajinách. Hoci tento svet všeobecne akceptuje nedokonalost', verejnost' trhovú nedokonalost' zväčša odmieta, najmä pod mediálno-politickým vplyvom. Pritom sa vel’mi neuvažuje o tom, že aj inštitúcie, ktoré majú nahrádzat’ nedokonalosti trhu, sú rovnako nedokonalé. V ekonómii sa nedokonalost' ako pojem objavuje v spojení „,nedokonalá konkurencia“, ktorá na rozdiel od dokonalej konkurencie, vyjadrujúcej len teoretickú abstrakciu umožňujúcu lepšie pochopenie konkurenčnej problematiky, odráža skutočnú podobu ekonomiky. Samotný pojem 
nedokonalost' je vel'mi dôležitý, umožňuje hlbšie pochopenie ekonomických kategórií a trhových procesov, ale aj širších spoločenských súvislostí, najmä pri využití poznatkov iných humanitných a spoločenských vied.

Analýzy viacerých ekonómov (učencov) v histórii dospeli k poznatkom, že protitrhové zameranie je hlboko zakorenený spôsob uvažovania v spoločnosti. Možno uviest' J. A. Schumpetera (významný ekonomický historik), podl’a ktorého je: „nevykorenitel’ný predsudok, že každé konanie, ktoré je vedené motívom zisku, musí mat' z tohto dôvodu protispoločenskú povahu“, (výrok uvedený v Caplan, 2010, s. 54). Teda nie je to nejaká odchýlka, ale hlboko zakorenený spôsob l’udského uvažovania. Na základe toho sa aj názory, presadzujúce sa cez hospodársku politiku o „limitovaní“ výšky zisku či presadzovaní „primeraného zisku“, javia ako „,dobrý nápad“.

$\mathrm{Na}$ druhej strane, už A. Smith sformuloval myšlienku, že zisk nie je žiadny milodar, ale výsledok obojstranne výhodnej výmeny. Vidina zisku pritom motivuje $\mathrm{k}$ znižovaniu nákladov, optimálnemu presunu zdrojov, ponuke nových tovarov a služieb, čo je dôležité aj pre verejný záujem aj pre všeobecný pokrok. Na Smitha sa neodvolávame z úcty $\mathrm{k}$ „zakladatel'ovi“, ale preto, že aj jeho súčasníci v dobe vrcholiaceho merkantilizmu trpeli predsudkami voči zisku a úroku a v podobe úžery ju odmietali dávno pred Smithom (islam odmieta akýkol’vek úrok).

Obdobný je aj iný predsudok voči trhu - monopolná tvorba cien - ignorujúci fakt, že ceny na trhu určuje predovšetkým dopyt a ponuka. $\mathrm{S}$ tým súvisí aj nenávist' $\mathrm{k}$ „sprostredkovatel'om“ medzi výrobcom a spotrebitel'om, ktorá je dlhodobou tendenciou podporujúcou myšlienky vykorist’ovania, špekulácií, monopolného zisku, cenových kartelov a pod. U nás aj vplyvom inercie komunizmu sa stále široko akceptuje myšlienka pripisujúca všetko zlo chamtivosti, ktorá najlepšie reprezentuje kapitalizmus ako stelesnenie nepoctivosti, neférovosti, klamstiev, ktoré umožňuje práve trh.

Práve ekonomická história, nielen teoretická, ale aj dejiny hospodárstva umožňujú poznat', že rozvoj obchodu neznamenal len rozvoj hospodárstva a spoločnosti, ale aj charakterových vlastností ako čestnost', zodpovednost', dôveryhodnost', dodržiavanie sl'ubov a pod. Historická dimenzia je dôležitá aj pri socialistickom učení, jeho vzniku, vplyve i rozpade v 20. storočí. Napriek ekonomickému zdôvodneniu neefektívnosti systému založenému na spoločenskom vlastníctve však najmä od začiatku 21. storočia narastajú sympatie aj u časti študentov k týmto myšlienkam. Akceptovanie Marxovej teórie aj medzi študentmi ekonómie istým spôsobom spochybňuje „úspešnost“، výučby ekonomickej teórie, a zrejme vyžaduje väčšiu pozornost'. 


\subsection{Trh práce a nezamestnanost'}

$\mathrm{V}$ mikroekonomickej oblasti, popri všeobecnej problematike trhu, postoja verejnosti $\mathrm{k}$ tejto inštitúcii a potrebe venovat’ väčšiu pozornost' v ekonomickom vzdelávaní i vo verejnom priestore tejto ústrednej téme, dôležitý význam má problematika spájajúca trhovú problematiku s úlohou l'udskej práce. V rámci trhu výrobných faktorov má osobitnú dôležitost' a prit’ahuje verejno-politický záujem trh práce, resp. v makroekonomickej verzii problematika nezamestnanosti (zamestnanosti). Aj tu sa prejavuje odmietanie trhu, dokonca ešte výraznejšie, nielen teoreticky, ale hlavne prakticky.

Historicky možno zvýšený verejno-politický záujem o túto problematiku spojit' $\mathrm{s}$ obdobím vplyvu Vel'kej depresie v tridsiatych rokoch minulého storočia, ktorej významnou črtou bola aj vysoká nezamestnanost' v postihnutých krajinách. Zabránit' negatívnym následkom tohto vývoja sa stalo po 2. svetovej vojne jednou z hlavných úloh rozširujúcej sa hospodárskej politiky, ktorú najlepšie dokumentuje zákon o zamestnanosti prijatý v roku 1946 v USA (Samuelson, Nordhaus, 1992, Hazlitt, 2008). Zabránit' vysokej nezamestnanosti sa stalo prvoradou úlohou hospodársko-politických opatrení a zrejme aj výrazného nárastu intervencionizmu. Prijímané a realizované opatrenia výrazne zvýšili štátne intervencie a regulácie aj $\mathrm{v}$ d’alších oblastiach. Bola to nielen reakcia na negatívne sociálne dopady nezamestnanosti, ale aj na čoraz silnejšie tlaky verejnosti na elimináciu trhových zlyhaní všeobecne.

Poznatok o trhovom znižovaní nákladov rastom technologického vybavenia a znižovaním potreby práce, vedúci k vyššej kvalite produkcie a zisku a predstavujúci úsporu práce, je často chápaný nie ako pokrok, ale nebezpečenstvo spočívajúce v prepúšt’aní pracovných síl, l'udí z práce. Trh sa stavia proti spoločenským záujmom „plnej zamestnanosti““. Túto anomáliu možno sčasti vysvetlit' absenciou chápania dynamiky hospodárskeho systému a objektívnej potreby zmien, sklonom k zotrvačnosti, stabilite v zmysle nemennosti.

Fungovanie trhu neustále tlačí na užitočné využívanie práce, tvoriacej tovary či služby, ktoré spotrebitelia akceptujú - kúpia. Len takáto práca je prospešná a vedie k prosperujúcej spoločnosti. Nejde teda (len) o to, aby každý práceschopný a ,práce žiadúci“ človek mal v danom čase pracovné miesto (na ktorom bude pracovat’ zo všetkých síl), ale o zvýšenie pomeru medzi dosiahnutými výsledkami a vynaloženou užitočnou prácou.

Odpor voči tomuto chápaniu možno nájst' $\mathrm{v}$ histórii už $\mathrm{v}$ počiatkoch industriálnej éry $\mathrm{v}$ hnutí luddistov $\mathrm{v}$ ich rozbíjaní strojov, ale aj v dobe Vel'kej depresie, kedy niektorí autori pripisovali vysokú nezamestnanost' technologickému pokroku, vplyvom ktorého rast 
produktivity práce postupne výrazne prevýši možnosti pracovných a investičných príležitostí, čo povedie k rastu nezamestnanosti, verejných dlhov a d’alších neduhov, ktoré spôsobia zánik kapitalizmu.

Ekonómom je spravidla zrejmé, že dynamika trhu vedie k neustálemu prispôsobovaniu sa novým podmienkam, pričom pracovné sily sa presúvajú tam, kde môžu byt' užitočné a staré pracovné miesta sú nahrádzané novými pracovnými príležitost’ami. Mení sa štruktúra ekonomiky a zamestnanosti. Jednoduchý príklad priblíži tieto zmeny. Ak v roku 1800 pracovalo v pol’nohospodárstve USA 95 zo 100 všetkých zamestnaných, tak v roku 1900 to bolo 40 a v roku 2000 len 3 zo 100 zamestnaných (Caplan, 2010).

Vplyvom trhu rastie sortiment ponúkaného tovaru a služieb, rastie ponuka zamestnaní, rastie spotreba a životná úroveň. Charakteristickou tendenciou v súčasnosti je posun hospodárskej štruktúry do sféry služieb. Ich charakter kvalitatívne mení ekonomickú efektívnost' a zásadne mení aj trh práce. Zvyšuje sa mobilita pracovných síl odrážajúca zrýchlovanie štrukturálnych zmien ekonomiky. Predovšetkým sa však mení logika zamestnanosti z industriálnej na terciárnu. Jej podstatou je premena pasívnej pracovnej sily čakajúcej na pracovné príležitosti v nových priemyselných podnikoch na aktívnu, ktorá musí na trhu hl'adat', akú užitočnú službu môže ponúknut' spotrebitel'om. Pritom je potrebný dostatočný ekonomický priestor - sloboda vol'by a rozhodovania pracovnej sily (človeka) - za minimálnych nevyhnutných noriem, jasných a jednoduchých pravidiel. Efektívnost' služieb predovšetkým $\mathrm{v}$ malých a stredných podnikoch znamená zásadnú kvalitatívnu zmenu ekonomickej činnosti, ktorú reprezentuje práve aktívna, tvorivá (kreatívna) pracovná sila ako výsledok nevyhnutných a adekvátnych zmien. Preto súčasná snaha udržiavat' pracovné miesta za každú cenu dotáciami a pod. je cestou k znižovaniu produktivity práce, plytvaniu zdrojmi a poklesu HDP. Rozsah možnej ponuky služieb je obmedzený len kreativitou producenta pracovnej sily - čo by mala akceptovat’ aj výučba ekonómie pri nadobúdaní kvalifikácie i rekvalifikácii.

Logika tendencie zmien hospodárskej štruktúry a nadväzujúcej štruktúry zamestnanosti je vo vzdelávacom procese ekonómov spravidla akceptovaná. Zásadnejšie nepochopenie sa prejavuje vo verejnosti všeobecne a osobitne $\mathrm{v}$ politickej sfére. Dôsledkom tohto nepochopenia je napríklad predimenzovaná priemyselná štruktúra slovenskej ekonomiky s minimálnym podielom progresívnych odvetví a stále poddimenzovanou a zastaranou sférou služieb sociálnych, zdravotných, vzdelávacích.

$\mathrm{Aj}$ adepti ekonómie $\mathrm{v}$ zásade chápu tieto tendencie a túto problematiku $\mathrm{v}$ zmysle ekonomických zákonitostí. Rozumejú tomu, že dôležitost' odvetví v hospodárstve sa nemeria 
počtom l'udí, ktorí v nich pracujú, že žiadúca je ekonomicky užitočná práca a jej úspory, že práca je skôr prostriedok ako ciel'. Chápu, že trhové sily rýchlo menia potenciálny technologický pokrok na reálny ekonomický prospech, ktorý v budúcnosti umožní napr. aj znižovanie pracovného času. Horšie je to s chápaním tejto problematiky verejnost'ou a politickou sférou, ktorá má reálny a dôležitý spoločenský a hospodársky vplyv, ale prijímané opatrenia vo vel'kej miere neodrážajú skutočný spoločenský a hospodársky záujem a potreby. Študenti spájali potrebné zmeny v hospodárskej štruktúre a zamestnanosti napríklad s tým, aby potenciálni politici absolvovali ekonomické vzdelanie.

\subsection{Trh vs. štát}

V makroekonómii je zásadnou problematika vzt’ahu trhu a štátu, resp. ekonomiky vs. politiky. V dnešnej „zmiešanej ekonomike“, teoreticky sa odrážajúcej v ekonomickom mainstreame, sa obe sféry značne prelínajú a v časti verejnosti dokonca stotožňujú, najmä v konaní štátu, jeho hospodárskej politike. Niektoré prvky tohto vzt'ahu robia problém aj v ekonomickom vzdelávaní. Vo všeobecnosti sú ale zásadné rozdiely v charaktere vzt'ahov medzi oboma sférami. Pokial' trhové ekonomické vzt'ahy sú v podstate dobrovol'né, založené na vlastných rozhodnutiach subjektov, politické vzt’ahy charakterizujú mocenské prvky, nástroje donútenia, násilia odrážajúce nedobrovol'né vzt’ahy.

Dlhodobo sa preto politika vnímala ako „nutné zlo“, ktorého dôsledkom boli konflikty, vojny, a pod. Až od 19. storočia sa postupne mení pohl'ad na štát a politiku, najmä vplyvom hospodárskych a spoločenských zmien, ktoré vyvrcholili Vel'kou depresiou v 30. rokoch minulého storočia. Štát, ktorý má $\mathrm{k}$ dispozícii mocenské nástroje potrebné $\mathrm{k}$ relatívne rýchlemu riešeniu problémov, sa postupne stal predstavitel’om spoločnosti usilujúcej sa o jej spoločenské dobro a riešenie jej problémov. Využívanie mocenských nástrojov určených spočiatku na ad hoc riešenie problémov krízy sa po druhej svetovej vojne premenilo na permanentné zasahovanie a regulovanie hospodárskej činnosti. Rast vplyvu štátu na úkor trhu je zrejmý v celom povojnovom období, napriek obdobiam priaznivejším pre trh najmä v 80 . rokoch minulého storočia, kedy rozšírením priestoru pre trhovú reguláciu sa podarilo riešit' problém stagflácie a urýchlit’ technologické zmeny. Na dlhodobej tendencii k rozširovaniu štátu v ekonomike sa ale vel’a nezmenilo a súčasná zmiešaná ekonomika sa všeobecne vníma ako ,prirodzený stav““.

Hoci čast' ekonómov $\mathrm{v}$ mikroekonomickej teórii stále vychádza z metodologického individualizmu, všeobecná predstava o ekonomike (i spoločnosti) je už takmer storočie založená na kolektivizme. Znamená to nielen prioritu spoločenských (verejných) záujmov 
pred individuálnymi, ale aj snahu stotožnit' politické záujmy so spoločenskými a zrejme aj legálnu možnost' nerešpektovat' ekonomické zákonitosti.

V dobe zmiešanej ekonomiky a mainstreamu patrí pomer medzi trhovou a štátnou reguláciou k zásadným hospodársko-spoločenským problémom. Od toho sa odvíjajú aj rozdiely v názoroch ekonómov, pri ktorých nejde zväčša o odlišnú logiku ekonomického uvažovania, ale skôr o diferencované hodnotové nastavenie a preferencie, ktoré vedú $\mathrm{k}$ vyzdvihovaniu príslušných argumentov pri preferovanom názore, ekonomickej predstave. Diferencovanost' názorov vo verejnosti je vyššia najmä vplyvom nižšsieho ekonomického poznania a vedomia. $\mathrm{V}$ ekonomickom vzdelávaní by preto snaha o objektívnost' mala byt' spojená s prezentáciou podstaty všetkých relevantných koncepcií a ich rozhodujúcich prvkov a argumentov, pričom v hospodársko-politických témach možno využit’ každodenné poznatky $\mathrm{z}$ praxe.

Argumenty za zvyšovanie účasti štátu $\mathrm{v}$ hospodárstve sa opierajú predovšetkým o sociálne dopady vedúce $\mathrm{k}$ materiálnej nerovnosti v spoločnosti, ktorá sa vyhodnocuje ako nespravodlivá. Oproti tejto sociálnej nespravodlivosti stoja argumenty ekonomickej nespravodlivosti a ekonomických zákonitostí, ktorých zmysel aj študenti akceptujú ako prijatel'nú ekonomickú logiku. Pri reálnom fungovaní spoločnosti však spravidla preferujú, tak ako zrejme väčšina spoločnosti, hodnotové chápanie sociálnej spravodlivosti, ktoré je však zväčša v opozícií k ekonomickým zákonitostiam.

K hlavným argumentom ekonomického pohl’adu patria:

- rast štátnych zásahov obmedzuje individuálnu zodpovednost' a zvyšuje spoločenskú (ne)zodpovednost';

- vláda nemôže nikdy napodobnit' rozmanitost' a rôznorodost' individuálneho konania (Friedman, 1993);

- zvyšovanie individuálnej závislosti na štátnych inštitúciách a rozširovanie nárokovosti;

- plytvanie zdrojmi: - štát, kompetentní politici disponujú cudzími peniazmi, čoho dôsledkom je aj neefektívne využívanie zdrojov a zadlžovanie; - štátne služby sú menej efektívne, dopyt pri nich často prevyšuje ponuku pri nízko stanovených cenách a nie sú vol’ne dostupné všetkým;

- politické zneužívanie zdrojov je sprevádzané korupciou a klientelizmom;

- odkázanost' chudobných na dávky znižuje motiváciu samostatného proaktívneho úsilia o zmenu vlastnej situácie. 
Napriek týmto (i d'alším) argumentom verejnost' zväčša podporuje štátne intervencie, paternalizmus, ked’že umožňujú:

- zbavit' sa niektorých individuálnych nákladov,

- nárokovat' si na statky bez reciprocity,

- dotácie do pol'nohospodárstva vedúce k lacnejším potravinám (a plytvaniu),

- štátnu kontrolu - potravín, liekov - prispievajúcu k pocitu väčšej bezpečnosti,

- reguláciu cien znižujúcu individuálne náklady,

- stanovit’ minimálnu mzdu.

To, čo verejnost' na paternalizme odmieta, je najmä byrokracia, papierovanie. Bez nich by sa však t’ažko realizovali uvedené výhody, hoci štátne inštitúcie sú spravidla $\mathrm{z}$ tohto hl'adiska predimenzované, resp. t’ažko sa stanovuje nevyhnutný, potrebný počet úradníkov a úradov. Výsledkom mnohých intervencií a regulácií je často ochrana vybraných (našich) firiem pred konkurenciou, do ktorých sa prelievajú peniaze daňovníkov aj $\mathrm{v}$ podobe „korupčného“. Skreslenost’ názorov verejnosti - nedostatok informácií, znalostí, vzdelania podporuje rast intervencionizmu. Občania vyberajú do politiky l'udí sl'ubujúcich naplnit' predstavy voličov rastom výdavkov z verejných zdrojov. Pritom sa často prejavuje konflikt nedostatku informácií vs. nedostatku uvažovania.

Súčasnost' na jednej strane vzbudzuje predstavy, že veda o riadení našla optimálnu podobu regulácií vel'kých spoločenských systémov, že sa nemusíme prispôsobovat' meniacim sa podmienkam, ale tieto podmienky vieme prispôsobovat' našim želaniam - akési novodobé „poručíme větru dešti““, ktoré sa v kolektivistických názoroch objavuje prakticky pravidelne už od osvietenstva, pričom sa tieto názory rozširujú a zovšeobecňujú.

Paradoxne, (na druhej strane) zároveň neustále nachádzame nové dôvody k obavám. Americký ekonóm Caplan (2010) hovorí o „sklone k pesimizmu“ ako o jednom zo spoločenských predsudkov, ktorý vedie k úvahám, že je to vrodená vlastnost' nášho mentálneho systému. Pritom skreslenost' pohl'adu spôsobuje, že máme skôr obavy z trhových monopolov než z politických monopolov.

\section{Záver}

Zvyšovat' pochopenie užitočnosti ekonomického prístupu k l'udskému konaniu je dôležitý prvok ekonomického vzdelávania v ekonomickej teórii, na ktorom by však mali vo väčšej miere participovat' aj d’alšie spoločenské a humanitné vedy. Základ ekonomického vzdelania by u všetkých študentov mal byt' položený už na strednej škole, kde by získali základné poznatky o fungovaní trhu a následne by na týchto poznatkoch mohli stavat' počas 
vysokoškolského úsilia. Takýto prístup by aj univerzitám umožnil orientovat’ sa na prehĺbenie už získaných poznatkov a tiež dal možnost' viac rozvíjat' diskusiu o aktuálnych ekonomických témach, ktorá ale bez základných poznatkov nie je možná. Univerzity by mali byt' miestom dialógu a diskusií, ktoré by formovali názory študentov, ale aj precizovali argumenty pedagógov. Zároveň považujeme za vel'mi dôležité vnímat' ekonomickú teóriu v kontexte ostatných spoločenských vied, pretože len tak je možné hl'adat'/získat' pravdivý obraz o celej spoločnosti a jej fungovaní.

Ako druhý relevantný argument $\mathrm{v}$ prospech vzdelania $\mathrm{v}$ ekonomickej teórií je možné uviest' stále rastúcu potrebu budovania a získania kritického myslenia. V súčasnej spoločnosti ovplyvnenej do vel'kej miery pandémiou koronavírusu sa dennodenne stretávame s rôznymi predsudkami, konšpiráciami a hoaxami, ktorým je potrebné čelit'. A práve tu zohráva kritické myslenie svoju nezastupitel'nú úlohu. Ekonomická teória poskytuje neustále možnost' posudzovania relevantnosti rôznych názorov a hl'adania pravdy, čo výrazne napomáha rozvoju kritického myslenia nielen študentov, ale každého, kto chce získat' poznatky $\mathrm{v}$ tejto oblasti. Opät' je však potrebné vidiet' spoločenský charakter ekonómie a vnímania jej obsahu $\mathrm{v}$ interakcií s ostatnými spoločenskými vedami.

Pred učitel'mi ekonomickej teórie stojí nel'ahká úloha hl'adania nových spôsobov vysvetl'ovania ekonomickej teórie, nových pomôcok, ktoré by lepšie pomohli dnešným študentom porozumiet' podstate ekonómie. Za posledných 25 rokov sa výrazne rozšírilo využívanie digitálnych technológií a digitálneho obsahu učiva a na tento trend by mal reagovat' aj spôsob vyučovania ekonomickej teórie na stredných a vysokých školách. $\mathrm{Na}$ druhej strane však neustále zohrávajú svoju nezastupitel'nú rolu pri získavaní vzdelania v ekonomickej teórií diela najvýznamnejších ekonómov, s ktorými sa každý študent, ktorý chce pochopit' podstatu ekonómie, musí oboznámit'.

Grantová podpora: Príspevok bol podporený z prostriedkov grantovej agentúry APVV v rámci projektu Postavenie sociálnych a humanitných vied v spoločnosti: ich možnosti a limity [APVV-18-0122].

\section{Zoznam použitej literatúry}

[1] Caplan, B. (2010). Mýtus racionálního voliče. Praha, CZ: Nakladatelství Lidové Noviny.

[2] Friedman, M. (1993). Kapitalismus a svoboda. Praha, CZ: Liberální institut. 
[3] Hazlitt, H. (2008). Ekonomie v jedné lekci. Praha, CZ: Alfa Nakladatelství a Liberální institut.

[4] Heyne, P. (1991). Ekonomický styl myšlení. Praha, CZ: VŠE Praha.

[5] Horeháj, J. (2008). Vybrané spoločenské súvislosti trhu. B. Bystrica, SK: EF UMB.

[6] Samuelson, P. A., Nordhaus, W. D. (1992). Ekonómia I. Bratislava, SK: Bradlo.

[7] Sedláček, T. (2009). Ekonomie dobra a zla. Praha, CZ: 65. pole.

Adresa autorov: doc. PhDr. Jozef Horeháj, PhD., Ing. Ivana Kuráková, PhD., Ekonomická fakulta UMB, Tajovského 10, 97401 Banská Bystrica, Slovensko, ivana.kurakova@umb.sk 